\title{
Butoxamine Hydrochloride
}

National Cancer Institute

\section{Source}

National Cancer Institute. Butoxamine Hydrochloride. NCI Thesaurus. Code C64184.

The hydrochloride salt form of butoxamine, a selective beta-2 adrenergic antagonist.

Butoxamine is used primarily in animal and tissue experiments to identify beta-2

receptors and their function. 